\title{
Impact Customer Satisfaction Towards Quality Service for Delivery Process at Railway Station in Malaysia
}

\author{
Muhammad Farahan Bin Adenan \\ Malaysian Institute of Industrial Technology, Universiti Kuala Lumpur, Malaysia \\ * Corresponding author: mfarahan46@gmail.com
}

\begin{tabular}{|c|c|}
\hline Abstract & ARTICLE INFORMATION \\
\hline $\begin{array}{l}\text { Nowadays, the transportation sector is now an important infrastructure for boosting the global economy as } \\
\text { well as sponsoring national income as it is currently being expanded in urban and rural areas as well as helping } \\
\text { to manage the delivery smoothly and smoothly. Hence, this research aims to determine how the quality } \\
\text { services that can be handled during the delivery process are carried out through the railway. As well as the } \\
\text { study to determine the impact during the delivery process to customers to ensure that all the services provided } \\
\text { meet customer demand during the delivery process. In addition, this study also identifies the proposed } \\
\text { improvements in management aspects. Five dimensions in SERVQUAL are used as indicators to influence } \\
\text { customer satisfaction. In this study, five SERVQUAL dimensions must have a positive relationship with } \\
\text { customer satisfaction and to know which dimensions are most important and dominant based on this study. } \\
\text { Estimated sample size is determined because the sample size selection in accordance with the required } \\
\text { estimation required is an important consideration to be taken into account in this study. For this method, } \\
\text { researchers have identified several factors that can be used in major variables and secondary variables. For } \\
\text { this researcher, the main variables are for customer satisfaction and the second variable is the quality service } \\
\text { for the transmission process. At the end of the study, the researchers suggested some suggestions for the } \\
\text { relevant parties to give customers the advantage of using the freight forwarding process by train. }\end{array}$ & $\begin{array}{ll}\text { Received: } & \text { March } 2018 \\
\text { Revised: } & \text { July } 2018 \\
\text { Accepted: } & \text { October } 2018 \\
\text { DOI: } & \end{array}$ \\
\hline Keywords: Customer Satisfaction, Transportation, Quality, Services, Railway Stations.. & (C) Readers Insight Publication \\
\hline
\end{tabular}

\section{INTRODUCTION}

Transportation is one of the alternatives regarded as a driving force and income for some communities. In Malaysia, the public transport system is the most important aspect of the communication system for both urban and rural communities. As an increasingly developed country, the relationship system within the country should have the efficiency and advancement in both service and technology. Therefore, the Malaysian government has been working on making new reforms and strategies to improve the quality of public transport services to attract the public to use these services.

Malayan Railway Limited or KERETAPI TANAH MELAYU (KTM) is the main rail operator in Peninsular Malaysia. The railway system dates back to the British colonial era, when it was first built to transport tin. Previously known as the Federated Malay States Railways (FMSR) and the Malayan Railway Administration (MRA), Keretapi Tanah Melayu acquired its current name in 1962. The organisation was corporatized in 1992, but remains wholly owned by the Malaysian government. Fares are generally reasonable, but the low frequency of the intercity trains does not usually make them competitive with other modes of transportation due to frequent breakdowns.

The $1,000 \mathrm{~mm}$ gauge railway network in Peninsular Malaysia which is controlled by KTMB consists of two main lines and several branch lines. Most of the lines are made out of ballasted system and locally made concrete sleepers, which had replaced wooden sleepers as early as 1982 for the Kerdau-Jerantut and Sungai Yu-Tumpat lines. The total length of the network was $1,699 \mathrm{~km}$, however due to the closure and subsequent removal of the section of tracks between Tanjong Pagar railway station and Woodlands Train Checkpoint, the new total length of the network is $1,677 \mathrm{~km}$. Since the trains run on select tracks, the benefit is as a rule free of blockage and thus a dependable and normal benefit has ended up a desire in life. Undoubtedly, any delays or intrusions on railroad benefit may bring a city to a stop, which may too carry a noteworthy financial misfortune and significantly influence day by day lives.

Wakaf Bharu railway station is a KTM train station at the named after the town of Wakaf Bharu, Kelantan. Wakaf Bharu is a small town in Tumpat district, Kelantan, Malaysia. Wakaf Bharu railway station on the East Coast Lines is located. Beside the mosque and several surau, there is also a church in Wakaf Bharu for non-muslin, more than 90 percent at this area are Malays and Muslims. Wakaf Bharu becomes crowded on Friday because there is a well know market called "Friday Market" at the "Pasar Besar Wakaf Bharu" or Wakaf Bharu Big Market near the Wakaf Bharu railway station. In this chapter, the objective of this research, the scope of the research, purpose of the research and the problem statement will be explained thoroughly. This reserach will give an overview about the customer satisfaction on KTM (KERETAAPI TANAH MELAYU) intercity. A case study for delivery process perspective located at railways station Wakaf Bharu. The target for this research is customer that using KTM at station Wakaf Bharu. Transport means transporting goods from place to another. It also serves as a media linking one location to a different location and enabling human movement. Transport sector is now an important infrastructure 
improving the global economy and development of Malaysia because one of the important links in Malaysia is the transport of the train.

Rail transport has been established in Malaya since the late 19th century with the aim of expedites the transportation of tin ore from mining to ports along the cost. Now the rail transport is one of the most important modes of transport in the country. This growth is growing and growing to meet customer demand to move from one place to another. Specifically, customer use train to travel to nearby place, to send or deliver the goods from another place for example to the long distance place from Kelantan to Johor Baharu.

Although the price to deliver the goods are increasing from time to time, people will still choose to use train for easy to deliver the large or many goods in one term for not waste the time for deliver. Customers are still concerned about whether their goods will reach the destination safely or not. This because that deliver process is depend on their safety and security how to the KTM Company manages the train and the driver for deliver that goods.

The purpose of this project is to identify issues that the customer faces during the delivery process at railway station Wakaf Bharu. The current issues that will occur during the delivery process will slow the delivery of the process and cause the delivered item to not reach the just in time. Besides that the damage to the vehicle in the delivery process is a problem faced by the customer due to unpredictable damage during the delivery process. Other issues during the delivery process are the loss of the goods to the customers during the delivery process will cause the missing item to be recovered and will be forced to compensate for the lost item.

The purpose of the research is as follow by conducting this investigation; it is possible to inform the level that result in satisfaction with delivery process at the KTM and examines the relationship between each aspect delivery process with satisfaction level of the customer. The scope of the study is focus on customer satisfaction while using a rail service for delivers that target passengers at Wakaf Bahru Railway Station.

\section{LITERITURE REVIEW}

Travel administrations quality has for quite some time been perceived as an imperative factor in impacting travellers and terminals quality is unquestionably part of it. Railways station quality can be additionally decayed into a few parts including getting an access, subjective and target security, lighting, climate control, data accessibility and stylish quality. (Mohajeri \& Amin, 2010) The railway station site-determination issue as a progression show comprising of four levels, each with its own primary criteria. The principle criteria are: (1) rail related, (2) passenger services, (3) architecture and urbanism, and (4) economics aspects. Every one of these primary criteria is then partitioned into a few sub criteria, giving an aggregate number of 26 sub criteria for finding worldwide needs among the potential railway stations.

According to Brons, Givoni, \& Rietveld,(2009) the access journey of rail explorers to the railway stations, concentrating on the decision of movement mode for this excursion and how it changes, for instance with distance to the station. This paper proceeds with the line of research on get to journey to railway stations and it has two aims. To begin with, to set up how critical passengers see the entrance to the railway station to be in their general fulfilment with the rail travel. Second, to examine the part of the railway station openness in the affinity to utilize rail by evaluating the harmony between the rail benefit offered, the entrance to railway stations and the characteristic of the customer served in influencing rail utilize. According to the research by Andrich, Mathiassenb, Hoogerwerfc, \& Gelderblomd, (2013) most service delivery put limits to the arrangement of assistive arrangement that are qualified for open arrangement. Some systems have a broader scope, with a lot of items included as qualified for funding. Service delivery process can be reengineered in ways that enhance proficiency and results without put a resources. Powerful general wellbeing organizations are those that tune in to their customers to make service forms that meet or surpass customer desires. Such data can help inform about whether changes in service delivery are required and whether a procedure reengineering or upgrade system is important to accomplish program objective. ( Boe, Riley, \& Parsons, 2009) Most service delivery process is not sufficiently adaptable to take the pace of these headways and take advantage of state the technology for the best benefit of their citizens, to build service viability and effectiveness.

From the research by Carrel, Mishalani, Wilson, Attanucci, \& Rahbee (2010) service control the errand of actualizing the timetable in day by day activities on a metro line assumes a key part in service delivery, since it impacts the nature of the service gave to customers. Significance of service control has been noted in light of the fact that a system expected to cure some of these deficiencies is proposed. An imperative component of this structure is the depiction of the full choice condition in which service control happens. On the basis of insights gained from extended visits to a control centre, the reliability of the system is found to depend on many endogenous factors. These elements were not beforehand perceived in a far reaching way by either researchers or practitioners. Beside the destinations of keeping up satisfactory levels of service from an activities point of view and limiting the effect of timetable deviations on travellers, the management of team and moving stock, safety, and framework limit are significant contemplations in service control choices.

In dealing with the impacts of a disruption or congestion-induced delay and in recuperating from them, controllers work with on-going data on the condition of the framework and fall back on a menu of changes that can be made (i.e., service control mediations) to accomplish a desired state. Those progressions include train-related interventions, for example, holding a train at a station or dispatching it early, communicating it (skipping stations), crossing out a whole train trip or including an unscheduled trek, short-turning a train, broadening it past its booked goal, pulling back it from traveller service rashly, or, if the line has branches, occupying it to an unexpected branch in comparison to it was initially planned to serve. A further arrangement of critical service control choices is identified with prepares needs at intersections and terminals, which can impact service quality all through the line. Despite the fact that the train related mediations influence prepares and teams alike, there are additionally a few group related intercessions that influence just team utilization, for example, substituting an extra driver or changing the location or time of a crew relief. ( Carrel, Mishalani, Wilson, Attanucci, \& Rahbee, 2010)

One can conceptualize transit service plan and delivery as a threestage process. The vital choices, formalized in the service arrangement and service design building up (e.g., traverse of service, recurrence, and steering) are made at the transit organization's administration levels. These choices are generally in light of expected or genuine request, monetary constraints, and political contemplations, and they fill in as contribution for the arranging division. Based on those sources of info, organizers build up an activities design depicting the utilization of organization assets to actualize the service strategy and service design by and by. The last piece inside the transit office meets up as day by day activities, which include all cutting edge staff and in addition vehicle and foundation upkeep divisions, engineers, and operational bolster work force. Preferably, the activities design ought to be donespecifically at this level; in all actuality, it regularly needs tweaking. Service control, which is a basic part at this operational level, manages and arranges the usage of the tasks design and alters it to adapt to unexpected occasions and here and now infeasibilities.

From the research Subashini \& Kavitha (2011) the cloud architecture poses a threat to the safety of existing technologies while being deployed in a cloud environment. Cloud service users must know how to understand the risks of data breaches in this new environment. In this paper, surveys of the various security risks that cause cloud phenomena are presented.

This article is a more specific survey for the various security issues that have been emitted due to the nature of the service delivery model of cloud computing. The threat of IT security is being introduced to other common, and multiple, including major challenges to transport and infrastructure domains. And infrastructure training on the ground in this area includes peanut communications. The same study was previously the most serious communication security risk technology in short-distance dedicated communications infrastructure architecture 
(DSRC) and the description was concerned with countermeasures, and with major threats of importance. However, training in communications infrastructure, communications and other infrastructure for cars in many ways, so many things involved, wireless technology is used to create predefined ones. (Lopez \& Aguado, 2015)

According to the journal Jo, Baek, Lee, Chae, \& Kim (2012) security for closed data link communication networks or opening their signal controls a fixed-line network cantered system developed as a technology to secure and evaluate the security of their signal control systems by developing message protection technologies delivered in response to a regular communications network that restoring rumours about errors of information flow and communication disruption.

Insurance provider, future claims cannot be fully anticipated. This risk, the actual nonconformity of expected losses, is significant and should be managed. Securitization transfers risks to the stock market, where the ability to understand these risks is greater than in the reinsurance market (Bae \& Kim, 2009).

From the research Lohse, Robledo, \& Schmidt (2010) that founded how many are in fear of their daily lives, they can buy insurance to protect potential loses but, these, too, to reduce the quality of personal for risk reduction. Key contribution, introduced the term "selfinsurance" (US) for companies to reduce the size and the loss of "protection" (SP) for companies to reduce the possibility of injury. For example, companies may install alarms to reduce the possibility of identity theft. Even though there is something that cannot buy safely to reduce potential losses. For example, all costs and benefits apply only to each other for owner, SI if SP are private goods.

According to the journal Ziel (2009) At the point when loss of or damage to merchandise, or an occasion or situation causing a delay in their delivery, happens amid the transporter's time of obligation yet exclusively before their stacking onto the train or exclusively after their release from the train, the arrangements of this Convention don't beat those arrangements of another global instrument that, at the season of such loss, damage or occasion or condition causing delay. The general view was that if the system standard were to be stretched out to issues other than obligation for loss of, or damage to, the goods (and delay), the change starting with one lawful administration then onto the next legitimate administration under a solitary contract of carriage may, from an operational or business outlook, make unworkable situations for the gatherings to the agreement.

From the journal by Naik, Gantasala, \& Prabhakar (2010) Service quality result a correlation of their before-service desires with their actual service encounter. The service will be viewed as great, if observations surpass desire, it will be viewed as great or sufficient, in the event that it just equivalents the desires, the service will be classed as terrible, poor or insufficient, on the off chance that it doesn "et meet them. (Awasthi, Chauhan, Omrani, \& Panahi, 2011) Service quality of urban transportation framework is essential to enhance efficiency, pick up benefit and increment consumer loyalty. All transportation associations convey assessment of their service quality all the time. This includes evaluation of different parameters identified with service quality for example, productivity, dependability, safety, and so on against their desired target value by the decision makers

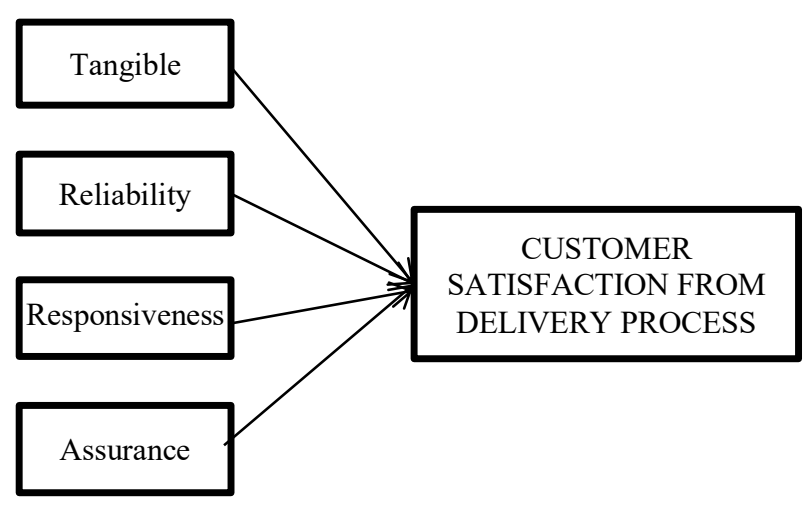

Figure 1: Research Framework
From the above conceptual framework, researchers have found that the independent variable and dependent variable are useful in this study. In this research, the dependent variable is customer satisfaction and the independent variable are five dimensional elements of Service Quality which is Tangibility, Reliability, Responsiveness, Assurance and Empathy in SERVQUAL that influence the customer satisfaction towards the service quality of express bus company services.

The SERQUAL model is used in this study to customer satisfaction toward quality service foe delivery process at railway station Wakaf Bharu. According to Ravichandran (2010) that research found SERVQUAL depends on the perception gap between the got service quality and the normal service quality, and has been generally embraced for explaining consumer perception of service quality. Initially 10 measurements of service quality were proposed (reliability, responsiveness, competence, access, courtesy, communication, credibility, security, understanding the consumer, and tangibles). Later these were decreased to five (tangibles, reliability, responsiveness, empathy, and assurances). The SERVQUAL measurement does not adequately explain a technical attribute of service. In other words, SERVQUAL focuses more on the service delivery process than on other attributes of service, such as service-encounter outcomes (i.e. technical dimensions).

From the research Meybodi (2011) founded that SERQUAL show is one of the models through some gap between desire and discernment examination to endeavour to gauge client service quality is the rate. This model likewise is known as the gap analysis model. SERQUAL as the most current strategies to gauge the quality of services gave, areas can challenge the current issues, give the business workplaces and expand its quality execution can help. In this manner, is prescribed to financier workplaces utilizing the above apparatuses, the quality of their services evaluated and fields give the quality change.

\section{RESEARCH METHODOLOGY}

This research used quantitative analysis. Quantitative analysis is considered to have as its main purpose the quantification of data. This allows generalizations of results from a sample to an entire population of interest and the measurement of the incidence of various views and opinions in a given sample. In addition, quantitative research is not infrequently followed by qualitative research which then aims to explore select findings further. To prevent facing problem in the future, the right skill of the data should be applied because this research will involving workers and customer at courier services company to accomplish.

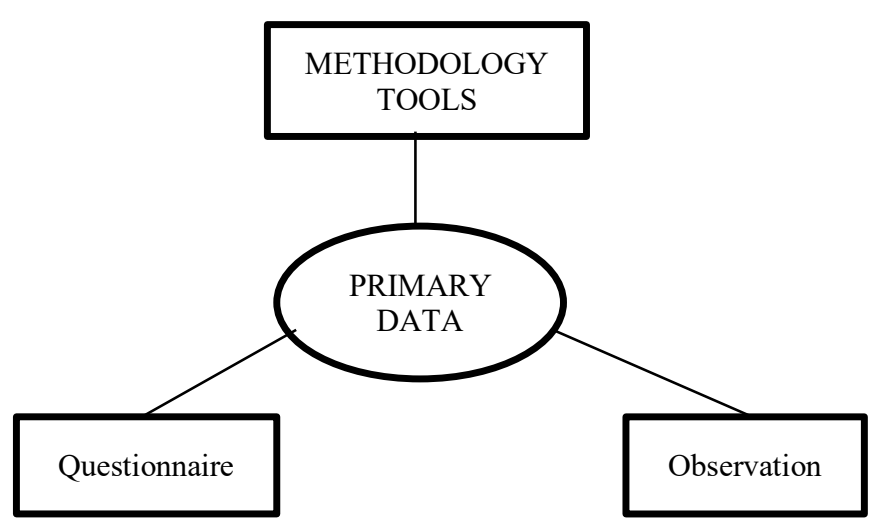

Figure 2: Primary Data

The primary data is the main data which can support to collect the informationn from the questionnaire. The purpose researcher doing this method is to study and also to gain information by direct experiences from target respondent. Therefore, from this data we will know what the result for outcome for this study which is come from the collected answer by questionnaire. The researcher will distribute the questionnaire to the workers and customer who directly working and use the service at the company. The graph presentation will explain 
more about the data collection of this research. All the data that collected from the respondents is analysed by using Statistical Package for the Social sciences (SPSS).SPSS is a computer application that provides statistical analysis of data. The researcher has used the SPSS application to achieve the research objectives.

The target respondents for this research will direct to the workers that works in the company and customers that use the company services. The estimate number of respondent is around 150 people. The questionnaire form will be distributed to the workers and customer the interview session will be conduct to specific person at customer satisfaction quality service towards for the delivery process.

To make sure this project success smoothly without miss any important aspect in the process, a flowchart was conducted to help us to stay focus what need to do in this project. The flow of this project was involve few step and that started from the selected from choose the project title, identify the problem statement, identify the scope and objective of the research, methodology that have be used, distribute the survey from, collect the data, and analysis the data project.

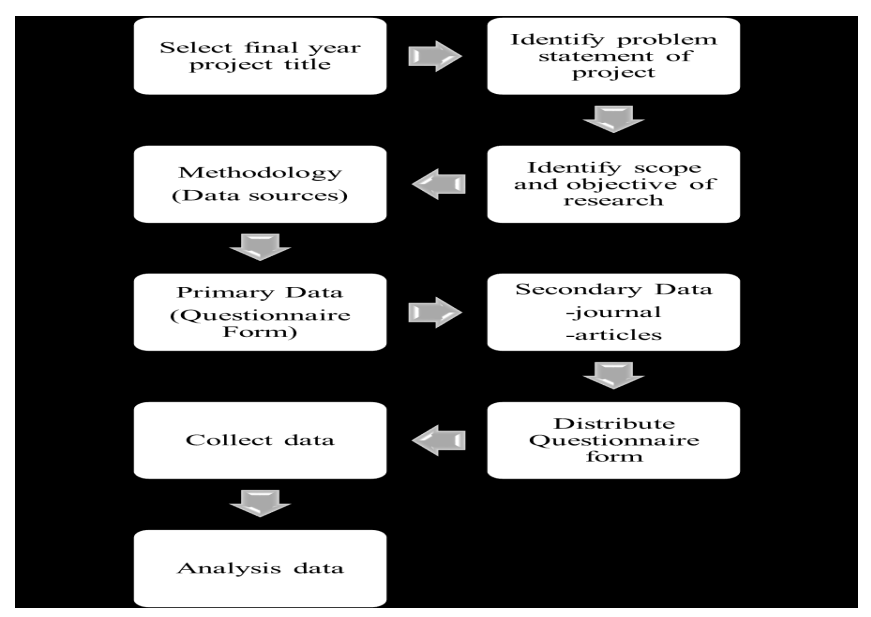

Figure 3: Research flow

The data analysis consists of evaluating the survey for the possibilities of some possible solution to finish this project. The survey form was use to collect data and make analysis to get the data for level of satisfaction of passenger for KTM service. The purpose of this analysis is to know the problem that been occur in KTM service, satisfaction of passenger, describe the procedure was used to collect the data, calculating of the data and provides the explanation of the right procedure used to analyze the data. For this method, the researcher can measure what is the factor can be used in primary variable and the secondary variable. For this researcher, the primary variable is for customer satisfaction and second variable is quality service for delivery process. For customer satisfaction, variable comprises five dimensions which are Tangibility, Reliability, Responsiveness, Assurance, and Empathy.

Before the survey on the passengers was carried out, an estimation of the sample size was determined as the selection of a sample size consistent with the required accuracy of the estimate was an important consideration to be taken into account in any survey.

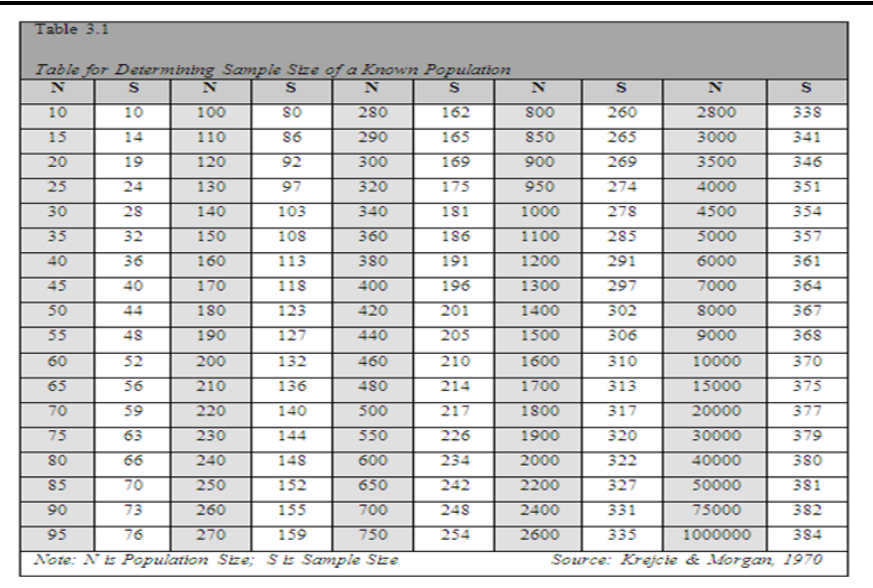

Figure 4: Morgan Table

The sample size is the number of observations used for calculating estimates of a given population. Sample sizes reduce expenses and time by allowing researchers to estimate information about a whole population without having to survey each member of the population.

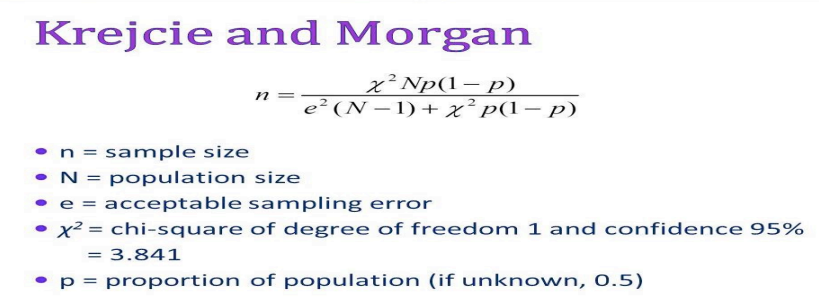

Figure 5: The formula Krejcie and Morgan

\section{RESULTS AND FINDINGS}

This part will explain about all the findings of this research. Here, the researcher has included the data, calculation and derived result with graph and charts. The graph presentation will explain more about the data collection of this research. All the data that collected from the respondents is analysed by using Statistical Package for the Social sciences (SPSS).SPSS is a computer application that provides statistical analysis of data. The researcher has used the SPSS application to achieve the research objectives.

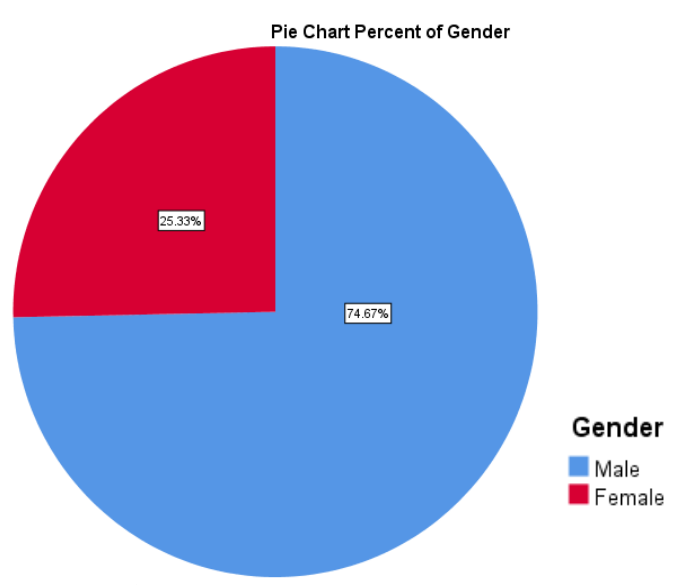

Figure 5: Gender

Based on chart above shows the result of total of respondents gender calculated. There is $74.7 \%$ which is 112 respondents from a male meanwhile $25.3 \%$ of 38 respondents are female. The pie chart show that the male respondent is higher than female respondent because male respondent is easy to approach while the observation period. 


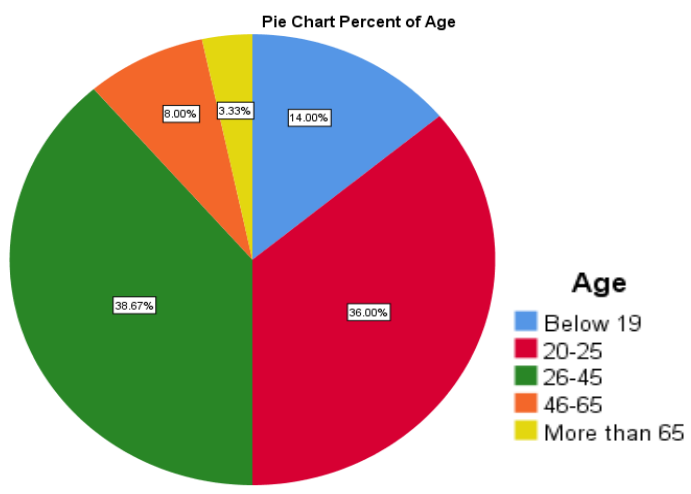

Figure 6: Age

Based on the chart above show the percentage of respondents classified into different range of age. From the table above also, it shows that the majority of respondent are $26-45$ years old which total $38.7 \%$ of 58 respondents, follow by the age $20-25$ years old which total $36 \%$ for 54 respondents. Third is below 19 years old with 21 respondents equal to $14 \%$. Next is $46-65$ years old with 12 respondents equal to $8 \%$ and lastly more than 65 years old with 5 respondent equal to $3.3 \%$.

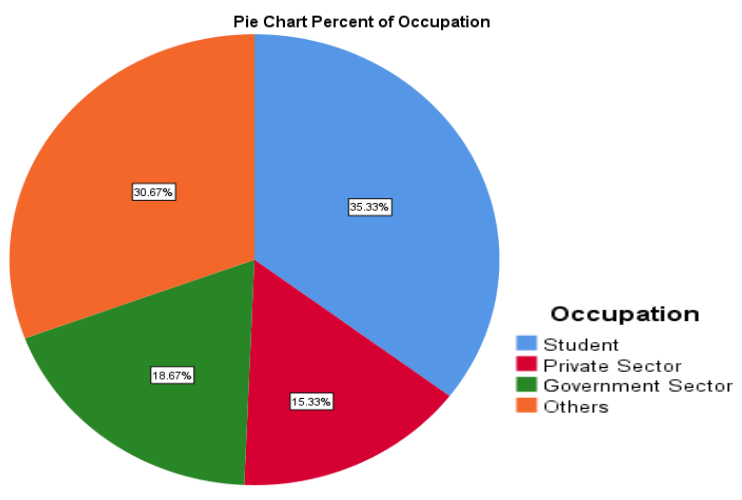

Figure7: Occupation

Based on the table above shows the total of occupation by the respondent and classified into four sectors which is student, private sector, government sector and others. From the table, it shows the majority respondents are consist of student which is 53 respondents equal to $35.3 \%$. Second, it be followed by the other occupation which is 46 respondents equal to $30.7 \%$ and the third is government sector which total $18.7 \%$ of 28 respondents. Lastly is private sector which totals $15.3 \%$ of 23 respondents.

Table 1: Variables Entered/Removeda

\begin{tabular}{llll}
\hline \multicolumn{4}{c}{ Variables Entered/Removeda } \\
\hline Model & Variables Entered & $\begin{array}{l}\text { Variables } \\
\text { Removed }\end{array}$ & Method \\
\hline 1 & SBE, SBT, SBP, SBR, & Enter \\
& SBAb &. & \\
\hline
\end{tabular}

a. Dependent Variable: CS

b. All requested variables entered.

Table 2: Model Summary

\begin{tabular}{lllllll}
\hline \multicolumn{7}{c}{ Model Summary } \\
\cline { 1 - 4 } Model & $\mathbf{R}$ & $\begin{array}{l}\mathbf{R} \\
\text { Square }\end{array}$ & $\begin{array}{l}\text { Adjusted } \\
\text { Square }\end{array}$ & $\begin{array}{l}\text { Std. Error of the } \\
\text { Estimate }\end{array}$ \\
\hline 1 & $.911 \mathrm{a}$ & .831 & .825 & .28586 & \\
\hline
\end{tabular}

The table above shows the regression data of the research. Based on the table above, it shows the $\mathrm{R}^{2}=0.831$. The represents $83.1 \%$ of variation in customer satisfaction is due to independent variables.
Table 3: ANOVA Test

\begin{tabular}{llllll}
\hline \multicolumn{6}{c}{ ANOVAa } \\
\hline Model & $\begin{array}{l}\text { Sum of } \\
\text { Squares }\end{array}$ & df & $\begin{array}{l}\text { Mean } \\
\text { Square }\end{array}$ & F & Sig. \\
\hline 1 Regression & 57.660 & 5 & 11.532 & 141.126 & $.000 \mathrm{~b}$ \\
$\quad$ Residual & 11.767 & 144 & .082 & & \\
\multicolumn{1}{l}{$\begin{array}{l}\text { Total } \\
\text { a. Dependent Variable: CS } \\
\text { b. Predictors: (Constant), SBE, SBT, SBP, SBR, SBA }\end{array}$} & & \\
\end{tabular}

The table above shows the ANOVA table of this research. Based on the table, it shows that the $\mathrm{f}=141.126$. The $\mathrm{f}$ value is more than 1.96 , this shows the model fitness.

Table: 4.Coefficients

\begin{tabular}{|c|c|c|c|c|c|c|}
\hline \multicolumn{7}{|c|}{ Coefficients } \\
\hline \multirow{2}{*}{\multicolumn{2}{|c|}{ Model }} & $\begin{array}{l}\text { Unst } \\
\text { Coeff }\end{array}$ & $\begin{array}{l}\text { lardized } \\
\text { ents }\end{array}$ & $\begin{array}{l}\text { Standardized } \\
\text { Coefficients }\end{array}$ & \multirow[b]{3}{*}{551} & \multirow[b]{2}{*}{ Sig. } \\
\hline & & B & $\begin{array}{l}\text { Std. } \\
\text { Error }\end{array}$ & Beta & & \\
\hline \multirow{6}{*}{1} & (Constant) & .079 & .143 & & & .583 \\
\hline & SBT & .522 & .061 & .517 & 8.538 & .000 \\
\hline & SBR & .134 & .067 & .131 & 1.989 & .049 \\
\hline & SBP & .046 & .064 & .047 & .720 & .473 \\
\hline & SBA & .364 & .075 & .365 & 4.828 & .000 \\
\hline & SBE & -.072 & .090 & -.069 & -.802 & .424 \\
\hline
\end{tabular}

Beta value $(-1$ to +1$)$

$\mathrm{T}$ value $(>1.96)$

$P$ value $(<0.05)$

From the table, $\mathrm{B}=$ Beta value, $\mathrm{t}=\mathrm{t}$ value and Sing. $=\mathrm{P}$ value.

Based on table, the hypotheses are made based on the beta value, $t$ value and $p$ value

a) Hypothesis for Tangibility

The beta value of Tangibility is 0.522 , with $t$ value is 8.538 and $p$ value is 0.000 . This indicates hypothesis Tangibility has a positive relationship with Customer Satisfaction. The hypothesis is accepted.

b) Hypothesis Reliability

The beta value for Reliability is 0.134 , with $t$ value is 1.989 and $p$ value is 0.049 . This indicates hypothesis Reliability has a positive relationship with Customer satisfaction. The hypothesis is accepted.

c) Hypothesis Responsiveness

The beta value for Responsiveness is 0.046 , with $t$ value is 0.720 and $p$ value is 0.473 . This indicates hypothesis Responsiveness has a negative relationship with Customer Satisfaction. The hypothesis is rejected.

\section{d) Hypothesis Assurance}

The beta value for Assurance is 0.364, with $t$ value is 4.828 and $p$ value is 0.000 . This indicates hypothesis Assurance has positive relationship with Customer satisfaction. The hypothesis is accepted.

e) Hypothesis Empathy

The beta value for Empathy is -0.072 , with $t$ value is -0.802 and $p$ value is 0.424. This indicates hypothesis Empathy has negative relationship with Customer Satisfaction. The hypothesis is rejected.

\section{DISCUSSION AND RECOMMENDATION}

From the research, the research found that quality service for delivery process at railway station Wakaf Bharu is very important to customer satisfaction. This study actually can be used by the railway station Wakaf Bharu to improve their quality service at delivery process to attract more people to use train for deliver goods and serve the good service to the users. The $\mathrm{R}^{2}$ represents $83.1 \%$ of variation in customer satisfaction is due to independent variables.

Based on the analysis, most of the respondents found that there are three main factors that have positive relationship contribute to the customer satisfaction which is Tangibility, Reliability and Assurance while, the Responsiveness and Empty have the negative relationship with customer satisfaction. Based on the hypothesis, the customer will 
satisfy if the railway station Wakaf Bharu takes action to improve the Tangibility, Reliability and Assurance.

At the end of this research study, researcher will give a few recommendation and suggestion about quality service for delivery process Tangibility, Reliability and Assurance based on the finding and discussion from the previous chapter. Based on the finding and data analysis improves their service to attract more people to use the railway station Wakaf Bharu.

Making an effort to improved facilities at station Wakaf Bharu, it has been the endeavour of the railways station to provide adequate amenities to the customers at the station. Amenities are further augmented from the time to time with growth in customers at station Wakaf Bharu, based on the felt need, and availability of funds. The various steps to improve the services and facilitate at railway station Wakaf Bharu such as senior citizens and persons with disabilities for customers requiring wheel-chair assistance, operated vehicle for carrying the item or goods before/after the train delivery and also have a Wi-Fi facility at station.

Customer demands are increasing and they have already had great customer experiences with other mode of transport that have provided delivery process. The best way to gain a loyal customer is by having awesome customer interactions and should build long lasting relationship with customer. This is the most basic form of communication between the customer and every single interaction is another opportunity for service to delight customer and retain them to use delivery process at railway station Wakaf Bharu.

There are many way to improve the old system at railway station Wakaf Bharu for recommendation can provide the EDI (electronic data interchange). The EDI (electronic data interchange) is a technique used by the many transporters such as land, rail, air and water that basically replace the old paperwork about the information customer for deliver with electronic data. There are a lot of delivery service uses this technique as it allows a much larger volume to be processed at the same time. Imagine that if railway station Wakaf Bharu use this system it can getting rid of all paperwork makes the process much quicker and faster to deliver process.

\section{References:}

Andrich, R., Mathiassenb, N.-E., Hoogerwerfc, E.-J., \& Gelderblomd, G. J. (2013). Service delivery systems for assistive technology in Europe: An AAATE/EASTIN position paper. Technology and Disability 25, 127. 146.

Boe, D. T., Riley, W., \& Parsons, H. (2009). Improving Service Delivery in a County Health Department WIC Clinic: An Application of Statistical Process Control Techniques. American Journal of Public Health, 16191625 .

Carlozzi , A. F., Bull, K. S., Stein, L. B., Ray, K., \& Barnes, L. (2002). Empathy Theory and Practice: A Survey of Psychologists and Counselors. The Journal of Psychology, 1-11.

Carrel, A., Mishalani, R., Wilson, N. H., Attanucci, J., \& Rahbee, A. (2010). Decision Factors in Service Control on High-Frequency Metro Line Importance in Service Delivery. Transportation Research Record: Journal of the Transportation Research Board, 52-59.

GSA, C., \& MGS, P. (2015). Service Quality (SQ) and its Impact on Passenger Satisfaction in Sri Lanka Railway Transport Service (SLRTS); Special Reference to Anuradhapura Railway Station. International Research Symposium Rajarata University of Sri Lanka, 351-361.

Naik, C. K., Gantasala, S. B., \& Prabhakar, G. V. (2010). Service Quality (Servqual) and its Effect on Customer Satisfaction in Retailing. European Journal of Social Sciences, 231-243.

Ziel, G. v. (2009). Multimodal Aspects of the Rotterdam Rules. 981-995.

Awasthi, A., Chauhan, S. S., Omrani, H., \& Panahi, A. (2011). A hybrid approach based on SERVQUAL and fuzzy TOPSIS for evaluating transportation service quality. Computers \& Industrial Engineering, 637-646.

Bae, T., \& Kim, C. (2009). Securitization of Motor Insurance Loss Rate Risks. Insurance: Mathematics and Economics, 1-31.

Blanchette, N. J., \& Sherman, D. (2001). CUSTOMER SATISFACTION AT WISCONSIN'S ONE-STOP JOB CENTERS: DEVELOPMENT AND IMPLEMENTATION OF A CUSTOMER SATISFACTION INSTRUMENT. 1-61.

Brons, M., Givoni, M., \& Rietveld, P. (2009). Access to railway stations and its potential in increasing rail use. Transportation Research Part A, 136149. 102
Deng, Z., Lu, Y., Wei, K. K., \& Zhang, J. (2009). Understanding customer satisfaction and loyalty: An empirical study of mobile instant messages in China. International Journal of Information Management, 289-300.

Ho, W. (2008). Integrated analytic hierarchy process and its applications - a literature review. European Journal of operational research, 1-39.

Hu, H.-H. (., Kandampully, J., \& Juwaheer, T. D. (2009). Relationships and impacts of service quality, perceived value,customer satisfaction, and image: an empirical study. The Service Industries Journal, 111-125.

Jamal, A., \& Anastasiadou, K. (2009). Investigating the effects of service quality dimensions and expertise on loyalty. European Journal of Marketing, 398-420.

Jo, H., Baek, J., Lee, K., Chae, E., \& Kim, Y. (2012). Wireless Security Method for On-board Centered Train Control System. computing and convergence technology (ICCT), 88-93.

Kuo, Y.-F., Wub, C.-M., \& Deng, W.-J. (2009). The relationships among service quality, perceived value, customer satisfaction, and postpurchase intention in mobile value-added services. Computers in Human Behavior, 887-896.

Lohse, T., Robledo, J., \& Schmidt, U. (2010). Self-Insurance and SelfProtection as Public Goods. Kiel Institute for the World Economy, 1-29.

Lopez, I., \& Aguado, M. (2015). Cyber Security Analysis of the European Train Control System. FUTURE RAILWAY COMMUNICATIONS, 110-116.

Meybodi, A. R. (2011). MEASURING SERVICE QUALITY USING SERVQUAL MODEL: A CASE STUDY OF BROKERAGE OFFICES IN IRAN. International Journal for Quality research, 657-666.

Mohajeri, N., \& Amin, G. R. (2010). Railway station site selection using analytical hierarchy process and data envelopment analysis. Computers \& Industrial Engineering, 107-114.

Ravichandran, K. (2010). Influence of Service Quality on Customer Satisfaction Application of Servqual Model. International Journal of Business and Management, 117-124.

SAPUTRA, A. D. (2010). ANALYSIS OF TRAIN PASSENGER RESPONSES ON PROVIDED SERVICE Case study: PT. Kereta Api Indonesia and Statens Järnvägar (SJ) AB, Sweden. Service Science Program Karlstad University Spring, 1-133.

Subashini, S., \& Kavitha, V. (2011). A survey on security issues in service delivery models of cloud computing. Journal of Network and Computer Applications, 1-11. 